\title{
Fluconazole inhibits human adrenocortical steroidogenesis in vitro
}

\author{
R van der Pas, L J Hofland, J Hofland, A E Taylor ${ }^{1}$, W Arlt ${ }^{1}$, J Steenbergen, P M van Koetsveld, \\ W W de Herder, F $\mathbf{H}$ de Jong and $\mathbf{R}$ A Feelders \\ Division of Endocrinology, Department of Internal Medicine, Erasmus Medical Center, room Ee 569, Dr Molewaterplein 50, 3015 GE Rotterdam, \\ The Netherlands ${ }^{1}$ School of Clinical and Experimental Medicine, Centre for Endocrinology, Diabetes, and Metabolism, University of Birmingham, \\ Birmingham, UK \\ (Correspondence should be addressed to R van der Pas; Email: r.vanderpas@erasmusmc.nl)
}

\begin{abstract}
The antifungal agent ketoconazole is often used to suppress cortisol production in patients with Cushing's syndrome (CS). However, ketoconazole has serious side effects and is hepatotoxic. Here, the in vitro effects of ketoconazole and fluconazole, which might be less toxic, on human adrenocortical steroidogenesis were compared. The effects on steroidogenesis were examined in primary cultures of nine human adrenocortical tissues and two human adrenocortical carcinoma cell lines. Moreover, the effects on mRNA expression levels of steroidogenic enzymes and cell growth were assessed. Ketoconazole significantly inhibited 11-deoxycortisol (H295R cells; maximum inhibition 99\%; $\mathrm{EC}_{50}$ $0.73 \mu \mathrm{M}$ ) and cortisol production (HAC15 cells; 81\%; $\mathrm{EC}_{50}$ $0 \cdot 26 \mu \mathrm{M}$ and primary cultures (mean $\left.\mathrm{EC}_{50} 0 \cdot 75 \mu \mathrm{M}\right)$ ). In cultures of normal adrenal cells, ketoconazole increased pregnenolone, progesterone, and deoxycorticosterone levels, while concentrations of 17-hydroxypregnenolone, 17-hydroxyprogesterone, 11-deoxycortisol, DHEA, and androstenedione decreased. Fluconazole also inhibited
\end{abstract}

11-deoxycortisol production in $\mathrm{H} 295 \mathrm{R}$ cells (47\%; only at $1 \mathrm{mM}$ ) and cortisol production in HAC15 cells (maximum inhibition $55 \% \mathrm{EC}_{50} 35 \mu \mathrm{M}$ ) and primary cultures (mean $\left.\mathrm{EC}_{50} 67 \cdot 7 \mu \mathrm{M}\right)$. In the cultures of normal adrenals, fluconazole suppressed corticosterone, 17-hydroxypregnenolone, and androstenedione levels, whereas concentrations of progesterone, deoxycorticosterone, and 11-deoxycortisol increased. Fluconazole $(1 \mathrm{mM})$ slightly increased STAR mRNA expression in both cell lines. Neither compound affected mRNA levels of other steroidogenic enzymes or cell number. In conclusion, by inhibiting $11 \beta$-hydroxylase and 17-hydroxylase activity, pharmacological concentrations of fluconazole dose dependently inhibit cortisol production in human adrenocortical cells in vitro. Although fluconazole seems less potent than ketoconazole, it might become an alternative for ketoconazole to control hypercortisolism in CS. Furthermore, patients receiving fluconazole because of mycosis might be at risk for developing adrenocortical insufficiency.

Journal of Endocrinology (2012) 215, 403-412

\section{Introduction}

Cushing's syndrome (CS) is characterized by chronic glucocorticoid excess and can be caused by an ACTHproducing pituitary adenoma (Cushing's disease, $\mathrm{CD}$ ), ectopic ACTH production by neuroendocrine tumors, or autonomous cortisol production by adrenal neoplasia (Boscaro et al. 2001, Arnaldi et al. 2003, Newell-Price et al. 2006). CS is associated with significant morbidity and, when uncontrolled, an increased mortality (De Martin et al. 2006, Newell-Price et al. 2006, Kelly 2007). In most cases of CS, the primary choice of treatment is surgery. Medical therapy is currently applied in CS to treat acute complications (e.g. psychosis), as pretreatment before surgery, after unsuccessful surgery, and in patients with inoperable neuroendocrine and adrenocortical tumors (van der Pas et al. 2012). The spectrum of medical therapy includes adrenal-blocking drugs, neuromodulatory agents that aim to inhibit ACTH production, and glucocorticoid receptor antagonists that counteract the effects of cortisol at tissue level (Schteingart 2009, van der Pas et al. 2012). Drugs blocking adrenal steroidogenic enzymes, like ketoconazole, etomidate, mitotane, and metyrapone, directly suppress production of cortisol (Fassnacht \& Allolio 2009, Patalano et al. 2009, Schteingart 2009, Veytsman et al. 2009). The antifungal agent ketoconazole, an imidazole derivative, is one of the most widely used drugs to lower cortisol concentrations in patients with CS (Engelhardt et al. 1983, Contreras et al. 1985, Loli et al. 1986, Boscaro et al. 1987, McCance et al. 1987, Farwell et al. 1988, Sonino et al. 1991, Vignati \& Loli 1996, Castinetti et al. 2008, Schteingart 2009). When administered at relatively high dosages, ketoconazole inhibits adrenocortical steroidogenesis by blocking steroidogenic enzymes, e.g. 17-hydroxylase and 11ß-hydroxylase (Santen et al. 1983, Engelhardt et al. 1985, Loli et al. 1986, Lamberts et al. 1987, Sonino 1987, Johansson et al. 2002, Veytsman et al. 2009, Ohlsson et al. 2010). However, ketoconazole has 
serious, mainly gastrointestinal, side effects and is hepatotoxic (McCance et al. 1987, Sonino et al. 1991, Como \& Dismukes 1994, Nieman 2002, Castinetti et al. 2008). On the other hand, fluconazole, another antifungal drug, has fewer side effects than ketoconazole (Como \& Dismukes 1994, Terrell 1999, Riedl et al. 2006) and may also inhibit adrenocortical steroidogenesis, as has been suggested in some case reports (Como \& Dismukes 1994, Albert et al. 2001, Shibata et al. 2001, Riedl et al. 2006, Santhana Krishnan \& Cobbs 2006, Schteingart 2009). The potency of fluconazole, which is a triazole derivative, has, however, not been directly compared to that of ketoconazole with respect to in vitro inhibition of human adrenocortical steroid production.

The aim of this study was, therefore, to compare the effects of fluconazole on adrenocortical steroid production to those of ketoconazole. We carried out in vitro studies with primary cultures of human adrenocortical tissue, as well as with two human adrenocortical carcinoma cell lines, with measurement of supernatant steroid concentrations and levels of mRNA encoding for steroidogenic enzymes. Finally, the effects of ketoconazole and fluconazole on cell growth and apoptosis were examined.

\section{Materials and Methods}

\section{Cell culture}

Human adrenocortical carcinoma H295R cells (ATCC, Manassas, VA, USA) and its clone HAC15 (kindly provided by Dr W Rainey, Medical College of Georgia, GA, USA; described in Wang et al. (2012)) were cultured in $75 \mathrm{~cm}^{2}$ flasks (Corning Costar, Schiphol-Oost, The Netherlands) in D-MEM/F12 (GIBCO Biocult Europe, Invitrogen) containing 5\% FCS, L-glutamine, and penicillin $10^{5} \mathrm{U} / 1$ (Bristol-Myers Squibb, Woerden, The Netherlands) at $37^{\circ} \mathrm{C}$ in a $5 \% \mathrm{CO}_{2}$ incubator. Once a week, the medium was refreshed and cells of both cell lines were harvested with trypsin $(0.05 \%)-$ EDTA $(0.53 \mathrm{mM})$ as described previously (van Koetsveld et al. 2006). All incubations were performed in quadruplicate and the cell line experiments were performed at least twice.

Human adrenal glands were collected during surgery of patients with cortisol excess due to cortisol-producing adrenocortical adenoma, ACTH-independent macronodular adrenal hyperplasia (AIMAH), and patients with normal adrenals undergoing surgery for renal cell carcinoma. Written informed consent was obtained from all patients before surgery. The study was approved by the medical ethics committee of the Erasmus Medical Centre. Diagnoses were histologically confirmed in all cases. Adrenal tissues were divided into pieces for different experiments. A part was taken up in Tissue-Tek (Sakura Finetek Europe, Zoeterwoude, The Netherlands), frozen, and stored at $-80{ }^{\circ} \mathrm{C}$ for later analysis. The remaining tissue was cut into small fragments of about $2-5 \mathrm{~mm}^{3}$. The fragments were washed in culture medium and centrifuged for $5 \mathrm{~min}$ at $600 \mathrm{~g}$. The medium was then refreshed and the tissue was stored overnight at $4{ }^{\circ} \mathrm{C}$. Cells were centrifuged again and the supernatant was removed. Collagenase type I (Sigma-Aldrich; $2 \mathrm{mg} / \mathrm{ml}$ ) in culture medium was added and the resulting suspension was incubated in a $37^{\circ} \mathrm{C}$ water bath for up to $2 \mathrm{~h}$. Subsequently, the suspension was filtered through a sterile surgical gauze (single layer) to remove any remaining large tissue fragments, after which it was centrifuged for $5 \mathrm{~min}$ at $600 \mathrm{~g}$. Cell suspension $(10 \mathrm{ml})$ was brought on $15 \mathrm{ml}$ ficoll (GE Healthcare, Uppsala, Sweden) and centrifuged for $20 \mathrm{~min}$ at $500 \mathrm{~g}$. The interphase was then collected in culture medium, viable cells were counted, and ultimately seeded in 24-well plates at a density of 100000 cells/well.

\section{Measurement of steroid hormone concentrations}

After $72 \mathrm{~h}$ of incubation, media were stored at $-20{ }^{\circ} \mathrm{C}$ until further analysis. Cortisol concentrations were measured using a nonisotopic, automatic chemiluminescence immunoassay system (Immulite; Siemens DPC, Inc., Los Angeles, CA, USA). 11-Deoxycortisol levels were estimated using a previously described RIA (Lamberts et al. 1987).

In addition, we carried out multi-steroid analysis by liquid chromatography/mass spectrometry (LC/MS) for accurate identification and quantification of pregnenolone, progesterone, deoxycorticosterone, corticosterone, 17-hydroxypregnenolone, 17-hydroxyprogesterone, 11-deoxycortisol, cortisol, cortisone, DHEA, androstenedione, and testosterone concentrations (Table 1). Steroids were extracted from $0.5 \mathrm{ml}$ of cell media via liquid/liquid extraction using $2.5 \mathrm{ml}$ tert-butyl-methyl-ether (MTBE). The mixture was frozen and the MTBE layer removed and evaporated under nitrogen at $55^{\circ} \mathrm{C}$. The sample was then reconstituted in $100 \mu \mathrm{l}$ of $50 \%$ of LC/MS grade methanol before LC/MS analysis. A Waters Xevo mass spectrometer with Acquity uPLC system was used fitted with a HSS T3, $1.8 \mu \mathrm{m}$, $1 \cdot 2 \times 50 \mathrm{~mm}$ column. The column temperature was maintained at $60^{\circ} \mathrm{C}$ throughout the experiments. The following settings were used: an electrospray source in positive ionization mode, capillary voltage $2 \cdot 0 \mathrm{kV}$, cone voltage $12-32 \mathrm{~V}$, collision energy $8-30 \mathrm{eV}$ (depending on the mass transition), a source temperature of $150{ }^{\circ} \mathrm{C}$, and a desolvation temperature of $600{ }^{\circ} \mathrm{C}$. A gradient system of (A) water with $0 \cdot 1 \%$ formic acid and (B) methanol with $0 \cdot 1 \%$ formic acid was optimized for resolution of the steroids. Steroids were quantified with respect to a calibration series, with appropriate internal standards, ranging from $0 \cdot 25$ to $500 \mathrm{ng} / \mathrm{ml}$. Each steroid was identified by a matching retention time and two mass transitions in comparison to a reference compound.

\section{Levels of $m R N A$ encoding for steroidogenic enzymes}

RNA was isolated from plated cells and homogenized adrenal tissues with Trizol reagent (Invitrogen) according to the manufacturer's protocol. RNA measurement, reverse 


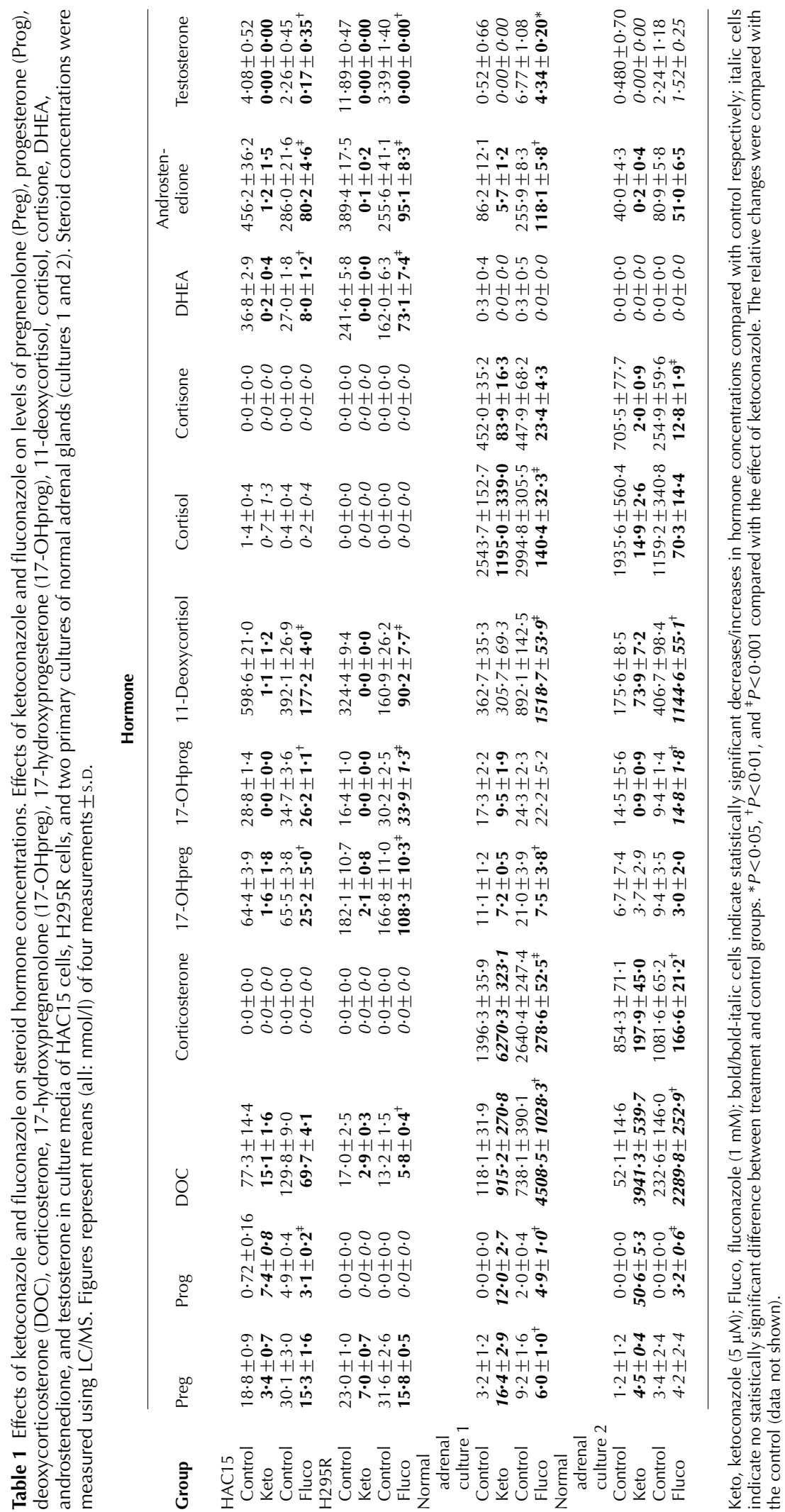


transcriptase reaction, and quantitative PCR (qPCR) were performed as described previously (Chai et al. 2010). The qPCR was performed in a $12.5 \mu \mathrm{l}$ volume for the housekeeping gene HPRT1 and steroidogenic enzymes STAR, CYP11A1, HSD3B2, CYP17A1, CYP21A2, and CYP11B1 (primer sequences have been reported in Chai et al. (2010)). After $72 \mathrm{~h}$, vehicle-controlled mRNA expression levels of steroidogenic enzymes were calculated relative to those of the housekeeping gene HPRT1 using the $\Delta C$ t method. Experiments were carried out three times in each cell line.

\section{Cell number/cell growth and apoptosis}

HAC15 cells were seeded in 24-well plates at a density of 50000 cells/well. H295R cells were seeded at a density of 100000 cells/well. Cells from primary cultures and both cell lines were allowed to attach overnight and were incubated with either ketoconazole $(0 \cdot 05-50 \mu \mathrm{M})$ or fluconazole $(5-1000 \mu \mathrm{M})$. Both agents were obtained from Sigma-Aldrich. After $72 \mathrm{~h}$ of incubation, DNA concentration per well (as a measure of cell number) was measured using the fluorescent dye Hoechst 33258 as described previously (Hofland et al. 1990). Apoptosis was measured using a commercially available ELISA kit (Cell Death Detection ELISA ${ }^{\text {PLUS }}$, Roche Diagnostics $\mathrm{GmbH}$ ). This assay detects the amount of DNA fragmentation as a measure of apoptosis. Measurements were performed using a Wallac Victor 2 multiplate reader.

\section{Statistical analysis}

We used one-way ANOVA followed by post hoc Dunnett's test to analyze the results on hormone production and cell growth in the dose-response experiments. Unpaired $t$-tests were used to analyze differences in steroid hormone concentrations between control and treated cells of the two primary cultures of normal adrenal glands described in Table 1. The same test was used to compare the effects of ketoconazole with those of fluconazole in the cultures described in Table 1. Significance was accepted at the 0.05 level of probability. Data on mRNA expression of steroidogenic enzymes in primary cultures and cell lines were analyzed using paired $t$-tests with Bonferroni correction.

\section{Results}

Effects on corticosteroid production

After $72 \mathrm{~h}$ of incubation, ketoconazole and fluconazole significantly inhibited cortisol production in HAC15 cells in a dose-dependent fashion with $\mathrm{EC}_{50}$ of $0 \cdot 26 \pm 1 \cdot 13 \mu \mathrm{M}$ (mean \pm S.E.M.) and $35 \pm 1 \cdot 22 \mu \mathrm{M}$ respectively (Fig. 1A). Maximum inhibition was $\sim 81 \%$ for ketoconazole $(P<0 \cdot 001)$ and $55 \%$ for fluconazole $(P<0 \cdot 001)$. In H295R cells, 11-deoxycortisol was measured instead of cortisol because these cells show a block in CYP11B1 expression
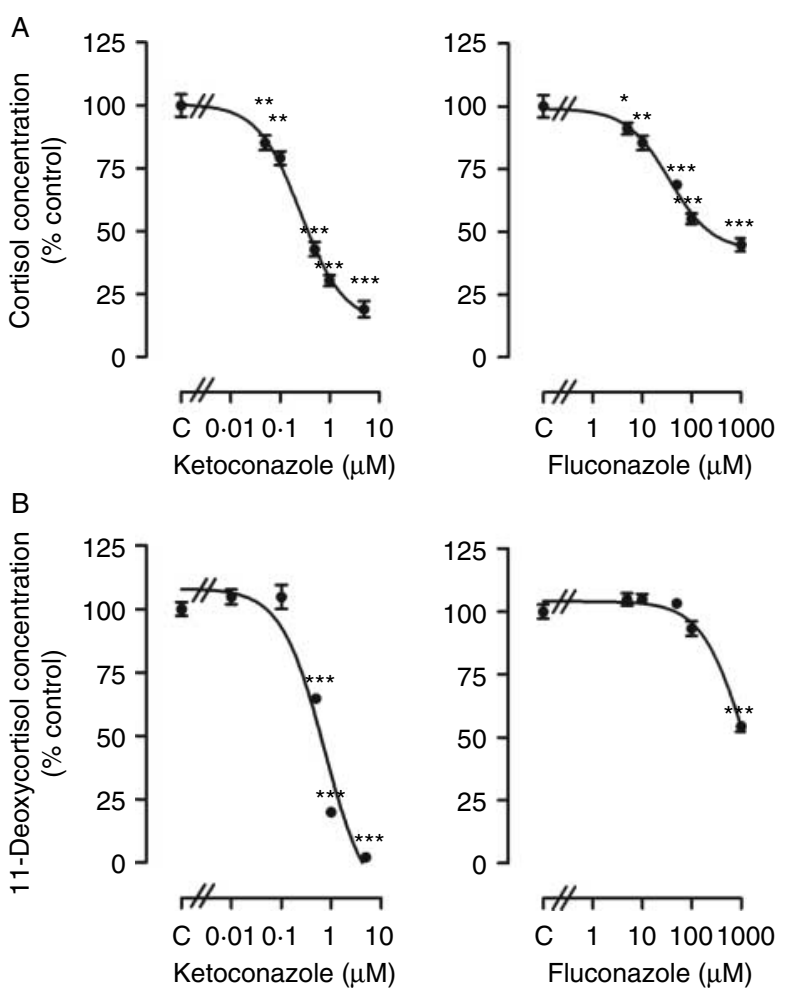

Figure 1 Dose-dependent effects of 72-h incubation with ketoconazole or fluconazole on (A) cortisol production by HAC15 cells and (B) 11-deoxycortisol production by H295R cells. Values are depicted as $\%$ of vehicle control and represent mean \pm s.E.M. C, control, ${ }^{* * *} P<0 \cdot 001,{ }^{* *} P<0 \cdot 01, * P<0 \cdot 05$ compared with control.

and therefore 11-deoxycortisol is produced in much larger quantities. In these cells, fluconazole inhibited 11-deoxycortisol production by $47 \%$ only at a concentration of $1 \mathrm{mM}(P<0 \cdot 001)$, while ketoconazole induced a profound dose-dependent decrease $\left(\mathrm{EC}_{50} 0 \cdot 73 \pm 1.74 \mu \mathrm{M}\right.$, maximal inhibition 99\%; $P<0 \cdot 001)$.

The effects of ketoconazole and fluconazole on cortisol production were also assessed in eight primary cultures of human adrenocortical tissue: two normal adrenal glands, three AIMAHs, and three cortisol-producing adrenocortical adenomas (Fig. 2). The effects of both drugs were evaluated in the same primary cultures of human adrenal glands. Both ketoconazole and fluconazole induced a significant dosedependent decrease in cortisol production in all cultures. $\mathrm{EC}_{50}$ values of ketoconazole-induced inhibition of cortisol production in cultures of normal, hyperplastic, and adenomatous adrenals were $0.82,0.53$, and $1.31 \mu \mathrm{M}$ respectively (overall $\mathrm{EC}_{50} 0.75 \mu \mathrm{M}$ ). For fluconazole, these values were $37 \cdot 9,88 \cdot 2$, and $57 \cdot 5 \mu \mathrm{M}$ respectively (overall $\mathrm{EC}_{50} 67 \cdot 7 \mu \mathrm{M}$ ).

Next to basal conditions, the effects of both compounds were examined in the presence of ACTH in one case. Figure 3 depicts a primary culture of the adrenocortical adenoma in which the effects of $72 \mathrm{~h}$ of incubation with either ketoconazole or fluconazole in the absence or presence 


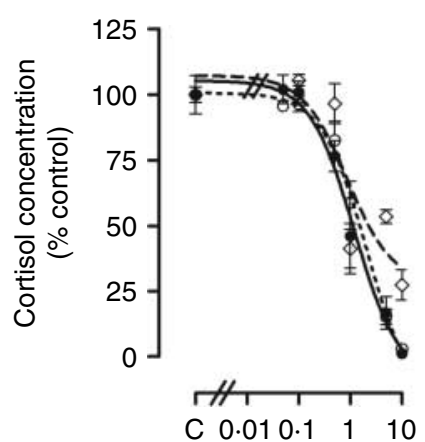

Ketoconazole $(\mu \mathrm{M})$

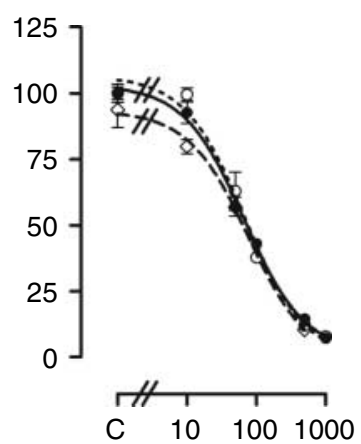

Fluconazole $(\mu \mathrm{M})$
Figure 2 Effects of 72 -h incubation with ketoconazole (left) or fluconazole (right) on basal unstimulated cortisol production by primary cultures, expressed as \% of vehicle control. Data represent mean \pm S.E.M. Closed circles and solid line, normal adrenal cortices $(n=2)$; open diamonds and thick broken line, ACTH-independent macronodular adrenal hyperplasias (AIMAH; $n=3)$; open circles and thin broken line, cortisol-producing adrenocortical adenomas $(n=3)$.

of ACTH $(250 \mathrm{pg} / \mathrm{ml})$ were measured. In terms of relative inhibition of cortisol production, both compounds had similar effects in the presence and absence of ACTH. In the presence of ACTH, cortisol production was inhibited by 64 and $100 \%$ by 1 and $10 \mu \mathrm{M}$ ketoconazole respectively $(P<0 \cdot 001)$. Without ACTH, these percentages were $66 \%(P<0 \cdot 01)$ and $97 \%(P<0 \cdot 001)$. In comparison, 50 and $500 \mu \mathrm{M}$ fluconazole inhibited cortisol production by 59 and $93 \%$ in the presence of ACTH $(P<0 \cdot 001)$, while these percentages were $65 \%(P<0.01)$ and $92 \%(P<0.001)$ in the absence of ACTH.

To determine the mechanism by which ketoconazole and fluconazole inhibit corticosteroid production, multi-steroid analysis was carried out using LC/MS. This included measuring the concentrations of pregnenolone, progesterone, deoxycorticosterone, corticosterone, 17-hydroxypregnenolone, 17-hydroxyprogesterone, 11-deoxycortisol, cortisol, cortisone, DHEA, androstenedione, and testosterone in culture media of both cell lines and the two primary cultures of normal adrenal glands (Fig. 4 and Table 1) after incubation with ketoconazole $(5 \mu \mathrm{M})$ or fluconazole $(1 \mathrm{mM})$.

Compared with control, ketoconazole induced an increase in progesterone production by HAC15 cells $(P<0 \cdot 001)$, while the amounts of pregnenolone $(P<0 \cdot 001)$, deoxycorticosterone $(P<0 \cdot 01)$, 17-hydroxypregnenolone, 17-hydroxyprogesterone, 11-deoxycortisol, DHEA, androstenedione, and testosterone (all: $P<0 \cdot 001$ ) were strongly decreased (Table 1). Fluconazole, on the other hand, decreased the amounts of all measurable steroids in HAC15 culture media, albeit in a less potent manner than ketoconazole. In H295R cell culture media, ketoconazole significantly suppressed the concentrations of all steroids. Fluconazole induced an increase in 17-hydroxyprogesterone concentrations $(P<0 \cdot 05)$, but as in HAC15 cell culture media, it decreased the concentrations of all other steroids in H295R cells.
In culture media of normal adrenal no. 1, concentrations of progesterone $(P<0 \cdot 01)$, deoxycorticosterone, and 11-deoxycortisol (both $P<0.001$ ) were significantly elevated compared with control after treatment with fluconazole. Concentrations of pregnenolone $(P<0 \cdot 05)$, corticosterone $(P<0 \cdot 001)$, 17-hydroxypregnenolone $(P<0 \cdot 01)$, cortisol $(P<0 \cdot 001)$, cortisone $(P<0 \cdot 01)$, androstenedione $(P<0 \cdot 001)$, and testosterone $(P<0 \cdot 01)$, on the other hand, were significantly decreased by treatment with fluconazole. Ketoconazole treatment increased concentrations of pregnenolone, progesterone, deoxycorticosterone, and corticosterone in culture media of this primary culture (all: $P<0 \cdot 001$ ), whereas concentrations of 17-hydroxypregnenolone, 17-hydroxyprogesterone, (both: $P<0 \cdot 01)$ cortisol, cortisone, and androstenedione (all: $P<0 \cdot 001)$ decreased significantly under ketoconazole treatment.

This pattern was also recognized in culture media of culture no. 2, with ketoconazole increasing the concentrations of pregnenolone, progesterone, and deoxycorticosterone
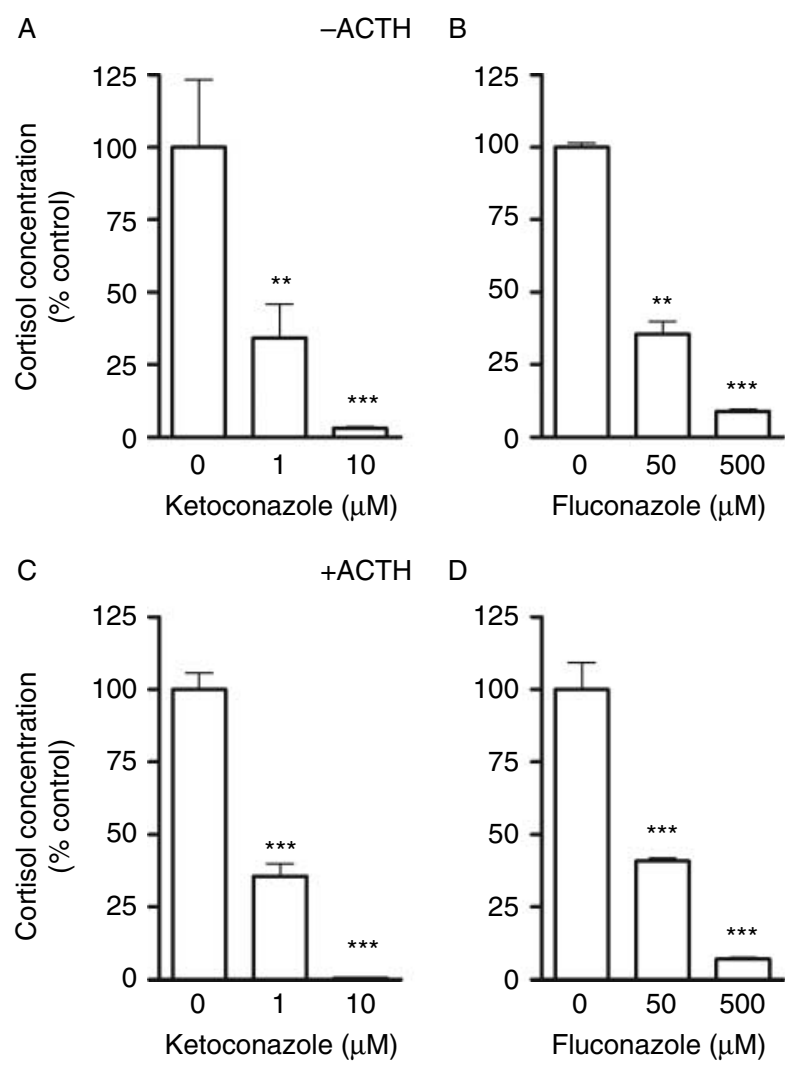

Figure 3 Effects of 72-h incubation with ketoconazole or fluconazole in the absence (A and B) or presence (C and D) of ACTH $(250 \mathrm{pg} / \mathrm{ml})$ on cortisol production in a primary culture of an adrenocortical adenoma. Results are depicted as \% compared with vehicle control and represent mean \pm S.E.M. Cortisol values in control groups: $1023 \pm 238$ (mean \pm s.E.M.) and $1142 \pm 16 \cdot 4 \mathrm{nM}$ (without ACTH), 5095 \pm 285 and $4250 \pm 393 \mathrm{nM}$ (with ACTH). $* * * P<0 \cdot 001 ; * * P<0 \cdot 01$ compared with vehicle control. 

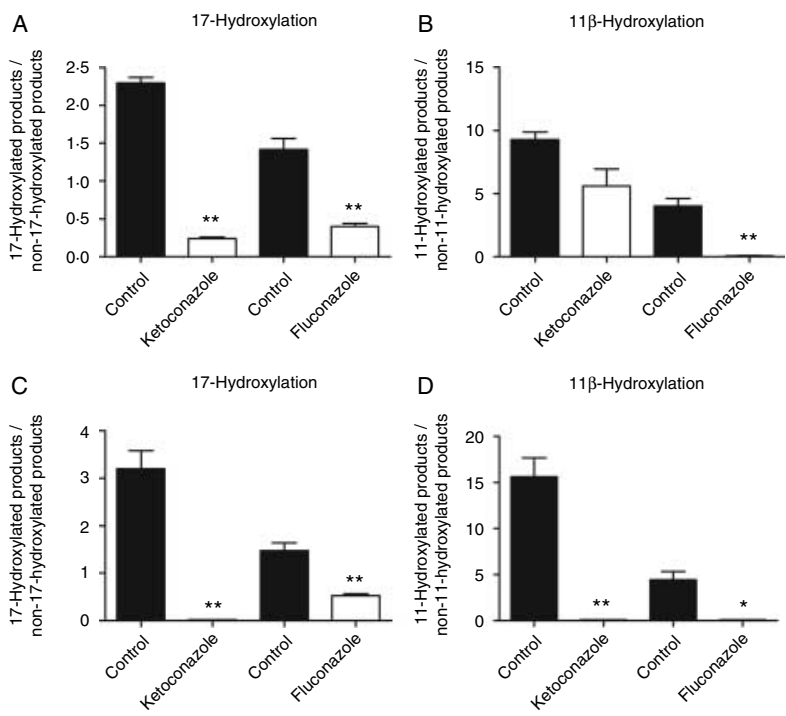

Figure 4 Effects of ketoconazole $(5 \mu \mathrm{M})$ and fluconazole $(1 \mathrm{mM})$ on 17-hydroxylation and 11-hydroxylation in two primary cultures of normal adrenal glands. (A and B) Culture 1; (C and D) culture 2. 17-Hydroxylase activity was calculated by dividing the sum of concentrations of 17-hydroxylated products (i.e. 17-hydroxypregnenolone, 17-hydroxyprogesterone, 11-deoxycortisol, cortisol, cortisone, DHEA, androstenedione, and testosterone) by the sum of concentrations of non-17-hydroxylated products (i.e. pregnenolone, progesterone, corticosterone, and deoxycorticosterone). 11-Hydroxylation was calculated by dividing the sum of concentrations of 11-hydroxylated products (i.e. cortisol, cortisone, and corticosterone) by the sum of concentrations of non-11-hydroxylated products (i.e. deoxycorticosterone and 11-deoxycortisol). $* * P<0 \cdot 01 ; * P<0 \cdot 05$.

$(P<0 \cdot 01)$ and suppressing concentrations of 17-hydroxyprogesterone $(P<0 \cdot 05), 11$-deoxycortisol $(P<0 \cdot 001)$, cortisol $(P<0 \cdot 01)$, cortisone, and androstenedione (both: $P<0 \cdot 001)$. In sharp contrast to the primary culture of the previous normal adrenal gland, ketoconazole significantly decreased corticosterone levels in media of this culture $(P<0 \cdot 001)$. In the same culture, fluconazole suppressed the concentrations of corticosterone $(P<0 \cdot 05), 17$-hydroxypregnenolone $(P<0 \cdot 001)$, cortisol, cortisone, and androstenedione (all: $P<0 \cdot 01)$, while it induced increases in concentrations of progesterone, deoxycorticosterone, and 11-deoxycortisol (all: $P<0 \cdot 001$ ).

When calculating the ratio between 17-hydroxylated and non-17-hydroxylated steroids, it was found that both ketoconazole and fluconazole significantly inhibited 17-hydroxylase activity in both patients, with ketoconazole having the most profound effect (Fig. 4). Fluconazole significantly inhibited 11-hydroxylation in both normal adrenal primary cultures as well, but ketoconazole only inhibited the activity of this enzyme in culture no. 2. As already mentioned, ketoconazole induced an upregulation of corticosterone in primary culture no. 1, but a statistically significant downregulation of this hormone in culture no. 2, which suggests a differential regulation of 11-hydroxylase activity by ketoconazole. In accordance with this finding, cortisol concentrations were more potently suppressed in patient 2 compared with patient 1 after treatment with ketoconazole (Table 1). In both cell lines, the ratio between 17-hydroxylated steroid concentrations and non17-hydroxylated steroid levels indicates that ketoconazole induces a firm decrease of 17-hydroxylase (data not shown).

\section{$m R N A$ expression levels of steroidogenic enzymes}

The effects of ketoconazole and fluconazole on mRNA expression levels of steroidogenic enzymes following $72 \mathrm{~h}$ of incubation are depicted in Fig. 5. In HAC15 cells, ketoconazole $(0.5$ or $5 \mu \mathrm{M})$ did not affect the mRNA expression level of any enzyme, whereas it significantly

A

HAC15

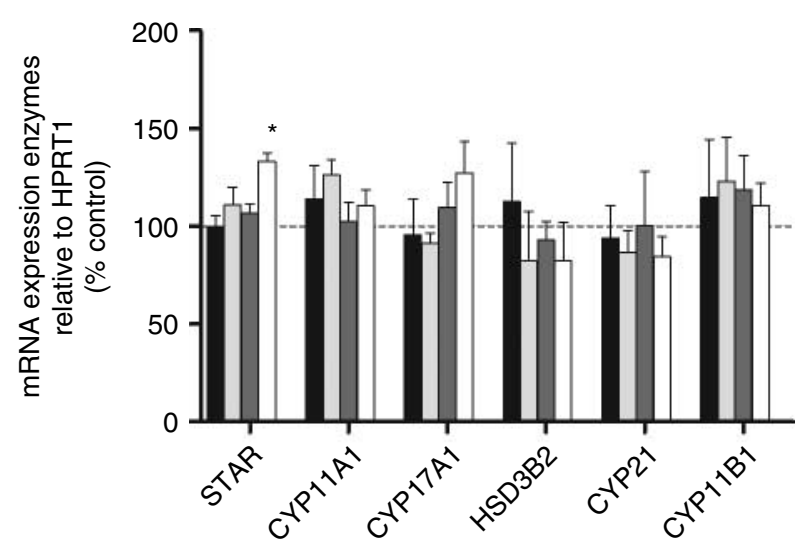

B

H295R

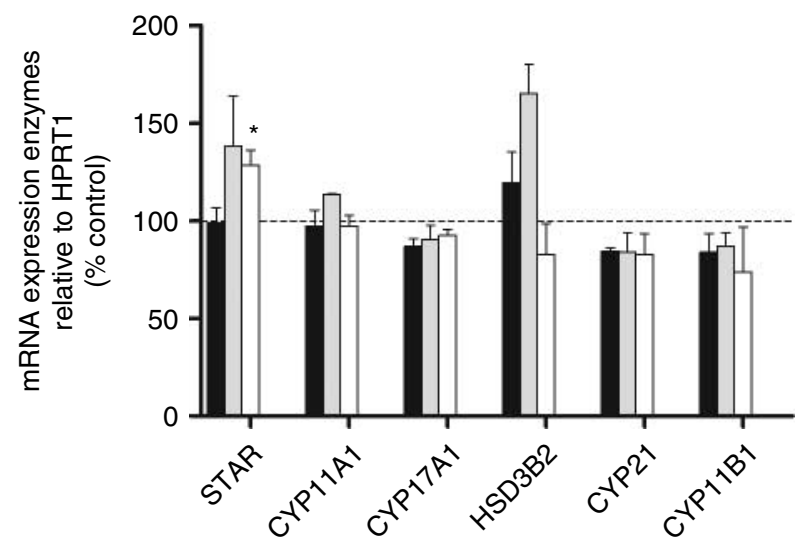

Figure 5 mRNA expression levels of steroidogenic enzymes in (A) HAC15 cells and (B) H295R cells following 72-h incubation with ketoconazole or fluconazole. Each graph represents the mean of three experiments. Data are normalized against the housekeeping gene HPRT1 and depicted relative to vehicle control. Data represent mean \pm S.E.M. Black bars: ketoconazole $0.5 \mu \mathrm{M}$; light gray bars: ketoconazole $5 \mu \mathrm{M}$; dark gray bars: fluconazole $50 \mu \mathrm{M}$; white bars: fluconazole $1 \mathrm{mM}$. ${ }^{*} P=0 \cdot 01$. 
decreased cortisol production in these concentrations (see above). Fluconazole (50 $\mu \mathrm{M}$ or $1 \mathrm{mM}$ ) did not suppress levels of mRNA encoding for steroidogenic enzymes either. In fact, in a concentration of $1 \mathrm{mM}$, it upregulated the mRNA expression of steroidogenic acute regulatory protein (STAR; $P=0 \cdot 01)$, the protein that facilitates cholesterol transport into the mitochondria of steroidogenic cells.

In H295R cells, mRNA expression levels of none of the steroidogenic enzymes were altered by ketoconazole. As in HAC15 cells, fluconazole increased the expression level of $\operatorname{STAR}(P=0 \cdot 01)$. We only used fluconazole in a concentration of $1 \mathrm{mM}$ because lower concentrations did not inhibit 11-deoxycortisol production in H295R cells.

In three primary cultures of AIMAHs treated with either ketoconazole or fluconazole, no significant effects on the expression of any of these mRNAs were found (data not shown).

\section{Cell growth and apoptosis in human adrenocortical carcinoma cell lines}

Finally, we examined the effects of ketoconazole and fluconazole on cell growth and apoptosis in both cell lines. Under the same experimental conditions as described in the experiments on hormone production, we observed no effect on cell growth, nor was there any induction of apoptosis in either cell line (data not shown).

DNA concentrations were measured in six out of nine cultures in which the effects on cortisol production were measured. In none of these six cultures (two normal adrenals, two AIMAHs, and two adrenocortical adenomas), we found an effect of either ketoconazole or fluconazole on DNA concentrations after $72 \mathrm{~h}$ (data not shown).

\section{Discussion}

Ketoconazole is frequently used to suppress cortisol production in patients with CS (Schteingart 2009, van der Pas et al. 2012). It inhibits adrenocortical steroidogenesis by interacting with cytochrome P450 enzymes (Lamberts et al. 1987, Johansson et al. 2002). However, ketoconazole has serious, mainly gastrointestinal, side effects that limit prolonged treatment and often lead to discontinuation of drug therapy (Sonino et al. 1991, Castinetti et al. 2008).

Several case reports described the effects of fluconazole, a triazole antifungal agent with less side effects (Como \& Dismukes 1994, Terrell 1999, Riedl et al. 2006), on adrenocortical steroidogenesis. While two studies reported that fluconazole in a dose of $400 \mathrm{mg}$ daily did not alter cortisol levels (Michaelis et al. 1993, Magill et al. 2004), other studies showed that fluconazole can already induce adrenocortical insufficiency even at lower concentrations, particularly in critically ill patients (Albert et al. 2001, Shibata et al. 2001, Santhana Krishnan \& Cobbs 2006). Riedl et al. reported decreased cortisol levels in a patient with CS who was treated with $200 \mathrm{mg}$ fluconazole daily because of sepsis. This is the only study that also examined the effects of fluconazole in vitro, although a rat adrenal adenoma cell line was used (Riedl et al. 2006).

In this study, we show that fluconazole can suppress human cortisol production in vitro, both in two human adrenocortical carcinoma cell lines and in primary cultures of human adrenocortical cells. In HAC15 cells, fluconazole dose dependently suppressed cortisol production, whereas it inhibited 11-deoxycortisol production in H295R cells only when added in the highest concentration $(1 \mathrm{mM})$. The observation that concentrations of virtually measured steroids decreased in culture media of both cell lines suggests that fluconazole exerts its effect at a level upstream of the 17-hydroxylase enzyme in these cell lines, e.g. by inhibiting STAR, the cytochrome P450 side-chain cleavage enzyme, or HSD3B2. Compared with fluconazole, ketoconazole inhibited cortisol and 11-deoxycortisol levels in a more potent manner in our cell lines, which is in agreement with what was found in a rat adrenocortical adenoma cell line (Riedl et al. 2006). The ratio between 17-hydroxylated steroid concentrations and non-17-hydroxylated steroid levels indicates that ketoconazole induces a firm decrease in 17-hydroxylase activity in both cell lines (data not shown), a mechanism that has already been described by Lamberts et al. (1987). As cortisol, cortisone, and corticosterone concentrations were at or below the detection limit in media of both control and treated cells, the effects of ketoconazole and fluconazole on 11-hydroxylase activity could not be determined in HAC15 and H295R cells.

As a proof of concept, we carried out the same experiment in nine primary cultures of human adrenocortical tissue. In these primary cultures, fluconazole dose dependently decreased cortisol production with an overall $\mathrm{EC}_{50}$ of $67 \cdot 7 \mu \mathrm{M}$, while the overall $\mathrm{EC}_{50}$ of ketoconazole-induced inhibition of cortisol production was $0 \cdot 80 \mu \mathrm{M}$. There was no difference between the inhibitory effects of ketoconazole and fluconazole in the three groups of adrenal tissues used. Similar to the pattern that was found in both cell lines, ketoconazole induced a block at the 17-hydroxylase level in both primary cultures of normal adrenal glands. A remarkable difference was found between the effects of ketoconazole on 11-hydroxylase activity of these normal adrenocortical cells. Whereas ketoconazole significantly inhibited the activity of this enzyme in the normal adrenal primary culture no. 2, no effect was found in culture no. 1. Accordingly, cortisol concentrations in culture no. 1 were decreased in a less potent manner compared with culture no. 2 after treatment of the cells with ketoconazole. Moreover, fluconazole (although used in a higher concentration) more potently inhibited cortisol concentrations compared with ketoconazole in this culture, a finding that contrasts with what was found in our cell lines and other primary cultures. Our observation in culture no. 2 is in accordance with what Engelhardt et al. (1985) reported, as they also found a ketoconazole-induced inhibition of $11 \beta$-hydroxylase activity. The inhibitory effect 
of ketoconazole on both $11 \beta$-hydroxylase and 17-hydroxylase enzyme activities illustrates that this drug can also decrease androgen and aldosterone production. Ketoconazole has indeed been reported to have beneficial effects in castrationresistant prostate cancer (Van Allen \& Ryan 2009). Moreover, it has also been shown to decrease serum concentrations of aldosterone in patients with CD (Boscaro et al. 1987). However, in our cultures of normal adrenal cells, treatment with ketoconazole strongly increased concentrations of deoxycorticosterone, which also has mineralocorticoid effects. It is therefore unknown how treatment with ketoconazole would influence the net mineralocorticoid activity. In agreement with what we found for ketoconazole in normal adrenal culture no. 2, fluconazole not only inhibited 17-hydroxylase activity but was also found to completely attenuate the 11-hydroxylation in both primary cultures, an observation that was supported by the combination of decreased cortisol concentrations and increased 11-deoxycortisol levels.

In one primary culture of a cortisol-producing adrenocortical adenoma, enough cells were available to study the effects of ketoconazole and fluconazole both in the absence and in the presence of ACTH. It was found that both drugs inhibited the cortisol secretion to the same extent in the presence of ACTH as they did in the absence of ACTH. Thus, in this particular case, ACTH did not influence the cortisol-lowering effect of either drug. However, it has to be emphasized that this comparison has only been made in one culture, so it is hard to extrapolate the effects of ACTH on the cortisol-lowering potency of both drugs to other situations.

The marked differences in steroid production between adrenocortical carcinoma cell lines and primary cultures of normal adrenal glands indicate that these cell lines do not provide a good model to investigate steroid biosynthesis. Although the effects of inhibitors of steroid production can be examined in HAC15 and H295R cells, these cells do not mimic the physiological situation.

To the best of our knowledge, this is the first study to report the mechanism of action of fluconazole on human steroidogenesis. Despite the fact that ketoconazole and fluconazole are antifungal agents from different classes, they appear to have similar properties regarding their adrenalblocking action. In order to determine to what extent each steroidogenic enzyme is exactly inhibited by these agents, future studies could be performed in which cell lines transfected with the respective enzymes are treated with ketoconazole and fluconazole. This would provide a more pure situation, as the effects on only one enzyme at a time could be assessed, without the obscuring effects of steroids being further converted. Obviously, the drawback of such studies would be that they do not resemble the in vivo situation.

It has been previously reported that ketoconazole inhibits adrenocortical steroidogenesis by direct binding to cytochrome P450 enzymes, thereby impairing their activity (Ohlsson et al. 2010). However, the effects of ketoconazole and fluconazole in the concentrations that we used on mRNA expression levels of genes encoding steroidogenic enzymes have not been described earlier. In other words, these compounds might also decrease steroidogenesis by inhibiting the mRNA expression of cytochrome P450 enzymes. Ohlsson et al. examined the effects of ketoconazole on levels of mRNA of genes encoding for these enzymes in H295R cells. Although these authors observed a general downregulation of mRNA expression levels by very low dosages of ketoconazole $(0.03 \mu \mathrm{M})$, no significant inhibition was found (Ohlsson et al. 2010). In this study, neither ketoconazole nor fluconazole significantly inhibited mRNA expression levels of steroidogenic enzymes in HAC15 and H295R cells. In fact, at a concentration of $1 \mathrm{mM}$, fluconazole increased the expression of mRNA encoding STAR in both cell lines. In three AIMAH cultures, no significant effects of both drugs on the mRNA expression levels of steroidogenic enzymes were observed. These results suggest that the decrease in hormone production cannot be explained by alterations in mRNA expression levels of adrenocortical steroidogenic enzymes. Therefore, given our results and the earlier reported direct inhibition of enzyme activity by ketoconazole (Ohlsson et al. 2010), direct inhibition of enzyme activity is the most likely mechanism by which both ketoconazole and fluconazole inhibit steroidogenesis.

Previously reported serum concentrations of fluconazole range from $23 \mu \mathrm{M}$ in healthy volunteers receiving $400 \mathrm{mg}$ daily to $243 \mu \mathrm{M}$ in cancer patients suffering from mycosis receiving $1600 \mathrm{mg}$ daily (Anaissie et al. 1995, Marchetti et al. 2001, Bergner et al. 2006). However, it is important to realize that these values represent serum concentrations and not tissue concentrations of fluconazole. The $\mathrm{EC}_{50}$ values that we obtained for fluconazole-induced inhibition of cortisol levels in primary cultures and HAC15 cells are within the range of the previously reported therapeutic in vivo serum concentrations, implicating that fluconazole might be a valuable alternative for ketoconazole to control cortisol overproduction in CS.

Because of this effect, the adrenal function of patients treated with fluconazole because of fungal infections should be closely monitored. In particular, in patients on intensive care units, in whom optimal adrenal function is of vital importance, treatment with fluconazole can induce adrenal insufficiency (Albert et al. 2001, Riedl et al. 2006, Santhana Krishnan \& Cobbs 2006). Therefore, clinicians who treat these patients with fluconazole should be aware of this side effect. The effects of other imidazole or triazole derivatives in this context have not been extensively investigated yet, but regarding the effects of fluconazole, it is not unlikely that other antifungal agents might also affect adrenocortical steroidogenesis (Lamberts et al. 1987).

In conclusion, we show that pharmacological concentrations of fluconazole inhibit corticosteroid production in two human adrenocortical carcinoma cell lines and in primary cultures of human adrenocortical tissue. Based on our data in primary cultures of normal adrenal glands, fluconazole seems 
to block the activity of the 11-hydroxylase and 17-hydroxylase enzymes. Although fluconazole seems less potent than ketoconazole, our results indicate that fluconazole, while less toxic, might be an alternative for ketoconazole to reduce cortisol levels in patients with CS. Future studies should examine the efficacy and optimal dose of fluconazole in this context. Finally, patients treated with fluconazole because of mycoses should be carefully monitored because they might be at risk for developing adrenocortical insufficiency.

\section{Declaration of interest}

The authors declare that there is no conflict of interest that could be perceived as prejudicing the impartiality of the research reported.

\section{Funding}

This research did not receive any specific grant from any funding agency in the public, commercial or not-for-profit sector.

\section{Acknowledgements}

The authors thank Dr W Rainey for kindly providing the HAC15 cell line.

\section{References}

Albert SG, DeLeon MJ \& Silverberg AB 2001 Possible association between high-dose fluconazole and adrenal insufficiency in critically ill patients. Critical Care Medicine 29 668-670. (doi:10.1097/00003246-20010300000039)

Anaissie EJ, Kontoyiannis DP, Huls C, Vartivarian SE, Karl C, Prince RA, Bosso J \& Bodey GP 1995 Safety, plasma concentrations, and efficacy of high-dose fluconazole in invasive mold infections. Journal of Infectious Diseases 172 599-602. (doi:10.1093/infdis/172.2.599)

Arnaldi G, Angeli A, Atkinson AB, Bertagna X, Cavagnini F, Chrousos GP, Fava GA, Findling JW, Gaillard RC, Grossman AB et al. 2003 Diagnosis and complications of Cushing's syndrome: a consensus statement. Journal of Clinical Endocrinology and Metabolism 88 5593-5602. (doi:10.1210/jc.2003030871)

Bergner R, Hoffmann M, Riedel KD, Mikus G, Henrich DM, Haefeli WE, Uppenkamp M \& Walter-Sack I 2006 Fluconazole dosing in continuous veno-venous haemofiltration (CVVHF): need for a high daily dose of 800 mg. Nephrology, Dialysis, Transplantation 21 1019-1023. (doi:10.1093/ ndt/gfi284)

Boscaro M, Sonino N, Rampazzo A \& Mantero F 1987 Response of pituitary-adrenal axis to corticotrophin releasing hormone in patients with Cushing's disease before and after ketoconazole treatment. Clinical Endocrinology 27 461-467. (doi:10.1111/j.1365-2265.1987.tb01174.x)

Boscaro M, Barzon L, Fallo F \& Sonino N 2001 Cushing's syndrome. Lancet 357 783-791. (doi:10.1016/S0140-6736(00)04172-6)

Castinetti F, Morange I, Jaquet P, Conte-Devolx B \& Brue T 2008 Ketoconazole revisited: a preoperative or postoperative treatment in Cushing's disease. European Journal of Endocrinology 158 91-99. (doi:10.1530/EJE-07-0514)

Chai W, Hofland J, Jansen PM, Garrelds IM, de Vries R, van den Bogaerdt AJ, Feelders RA, de Jong FH \& Danser AH 2010 Steroidogenesis vs steroid uptake in the heart: do corticosteroids mediate effects via cardiac mineralocorticoid receptors? Journal of Hypertension 28 1044-1053. (doi:10.1097/HJH.0b013e328335c381)
Como JA \& Dismukes WE 1994 Oral azole drugs as systemic antifungal therapy. New England Journal of Medicine 330 263-272. (doi:10.1056/ NEJM199401273300407)

Contreras P, Rojas A, Biagini L, Gonzalez P \& Massardo T 1985 Regression of metastatic adrenal carcinoma during palliative ketoconazole treatment. Lancet 2 151-152. (doi:10.1016/S0140-6736(85)90251-X)

De Martin M, Pecori Giraldi F \& Cavagnini F 2006 Cushing's disease. Pituitary 9 279-287. (doi:10.1007/s11102-006-0407-6)

Engelhardt D, Mann K, Hormann R, Braun S \& Karl HJ 1983 Ketoconazole inhibits cortisol secretion of an adrenal adenoma in vivo and in vitro. Klinische Wochenschrift 61 373-375. (doi:10.1007/BF01485030)

Engelhardt D, Dorr G, Jaspers C \& Knorr D 1985 Ketoconazole blocks cortisol secretion in man by inhibition of adrenal 11 beta-hydroxylase. Klinische Wochenschrift 63 607-612. (doi:10.1007/BF01733014)

Farwell AP, Devlin JT \& Stewart JA 1988 Total suppression of cortisol excretion by ketoconazole in the therapy of the ectopic adrenocorticotropic hormone syndrome. American Journal of Medicine 84 1063-1066. (doi:10.1016/0002-9343(88)90312-9)

Fassnacht M \& Allolio B 2009 Clinical management of adrenocortical carcinoma. Best Practice \& Research. Clinical Endocrinology \& Metabolism 23 273-289. (doi:10.1016/j.beem.2008.10.008)

Hofland LJ, van Koetsveld PM \& Lamberts SW 1990 Percoll density gradient centrifugation of rat pituitary tumor cells: a study of functional heterogeneity within and between tumors with respect to growth rates, prolactin production and responsiveness to the somatostatin analog SMS 201-995. European Journal of Cancer 26 37-44. (doi:10.1016/02775379(90)90254-Q)

Johansson MK, Sanderson JT \& Lund BO 2002 Effects of 3-MeSO2-DDE and some CYP inhibitors on glucocorticoid steroidogenesis in the H295R human adrenocortical carcinoma cell line. Toxicology in Vitro 16 113-121. (doi:10.1016/S0887-2333(01)00111-4)

Kelly DF 2007 Transsphenoidal surgery for Cushing's disease: a review of success rates, remission predictors, management of failed surgery, and Nelson's syndrome. Neurosurgical Focus 23 E5. (doi:10.3171/foc.2007. 23.3.7)

van Koetsveld PM, Vitale G, de Herder WW, Feelders RA, van der Wansem K, Waaijers M, van Eijck CH, Speel EJ, Croze E, van der Lely AJ et al. 2006 Potent inhibitory effects of type I interferons on human adrenocortical carcinoma cell growth. Journal of Clinical Endocrinology and Metabolism 91 4537-4543. (doi:10.1210/jc.2006-0620)

Lamberts SW, Bons EG, Bruining HA \& de Jong FH 1987 Differential effects of the imidazole derivatives etomidate, ketoconazole and miconazole and of metyrapone on the secretion of cortisol and its precursors by human adrenocortical cells. Journal of Pharmacology and Experimental Therapeutics $\mathbf{2 4 0}$ 259-264.

Loli P, Berselli ME \& Tagliaferri M 1986 Use of ketoconazole in the treatment of Cushing's syndrome. Journal of Clinical Endocrinology and Metabolism 63 1365-1371. (doi:10.1210/jcem-63-6-1365)

Magill SS, Puthanakit T, Swoboda SM, Carson KA, Salvatori R, Lipsett PA \& Hendrix CW 2004 Impact of fluconazole prophylaxis on cortisol levels in critically ill surgical patients. Antimicrobial Agents and Chemotherapy 48 2471-2476. (doi:10.1128/AAC.48.7.2471-2476.2004)

Marchetti O, Majcherczyk PA, Glauser MP, Bille J, Moreillon P \& Sanglard D 2001 Sensitive bioassay for determination of fluconazole concentrations in plasma using a Candida albicans mutant hypersusceptible to azoles. Antimicrobial Agents and Chemotherapy 45 696-700. (doi:10.1128/AAC.45. 3.696-700.2001)

McCance DR, Hadden DR, Kennedy L, Sheridan B \& Atkinson AB 1987 Clinical experience with ketoconazole as a therapy for patients with Cushing's syndrome. Clinical Endocrinology 27 593-599. (doi:10.1111/j. 1365-2265.1987.tb01189.x)

Michaelis G, Zeiler D, Biscoping J, Fussle R \& Hempelmann G 1993 Function of the adrenal cortex during therapy with fluconazole in intensive care patients. Mycoses 36 117-123. (doi:10.1111/j.1439-0507.1993. tb00698.x)

Newell-Price J, Bertagna X, Grossman AB \& Nieman LK 2006 Cushing's syndrome. Lancet 367 1605-1617. (doi:10.1016/S0140-6736(06)68699-6) 
Nieman LK 2002 Medical therapy of Cushing's disease. Pituitary 5 77-82. (doi:10.1023/A:1022308429992)

Ohlsson A, Cedergreen N, Oskarsson A \& Ulleras E 2010 Mixture effects of imidazole fungicides on cortisol and aldosterone secretion in human adrenocortical H295R cells. Toxicology 275 21-28. (doi:10.1016/j.tox. 2010.05.013)

van der Pas R, de Herder WW, Hofland L \& Feelders RA 2012 New developments in medical therapy of Cushing's syndrome. Endocrine-Related Cancer 13 171-179. (doi:10.1530/ERC-12-0191)

Patalano A, Brancato V \& Mantero F 2009 Adrenocortical cancer treatment. Hormone Research 71 (Suppl 1) 99-104. (doi:10.1159/000178049)

Riedl M, Maier C, Zettinig G, Nowotny P, Schima W \& Luger A 2006 Long term control of hypercortisolism with fluconazole: case report and in vitro studies. European Journal of Endocrinology 154 519-524. (doi:10.1530/eje.1. 02120)

Santen RJ, Van den Bossche H, Symoens J, Brugmans J \& DeCoster R 1983 Site of action of low dose ketoconazole on androgen biosynthesis in men. Journal of Clinical Endocrinology and Metabolism 57 732-736. (doi:10.1210/ jcem-57-4-732)

Santhana Krishnan SG \& Cobbs RK 2006 Reversible acute adrenal insufficiency caused by fluconazole in a critically ill patient. Postgraduate Medical Journal 82 e23. (doi:10.1136/pgmj.2006.047258)

Schteingart DE 2009 Drugs in the medical treatment of Cushing's syndrome. Expert Opinion on Emerging Drugs 14 661-671. (doi:10.1517/ 14728210903413522)

Shibata S, Kami M, Kanda Y, Machida U, Iwata H, Kishi Y, Takeshita A, Miyakoshi S, Ueyama J, Morinaga S et al. 2001 Acute adrenal failure associated with fluconazole after administration of high-dose cyclophosphamide. American Journal of Hematology 66 303-305. (doi:10.1002/ ajh.1063)
Sonino N 1987 The use of ketoconazole as an inhibitor of steroid production. New England Journal of Medicine 317 812-818. (doi:10.1056/ NEJM198709243171307)

Sonino N, Boscaro M, Paoletta A, Mantero F \& Ziliotto D 1991

Ketoconazole treatment in Cushing's syndrome: experience in 34 patients. Clinical Endocrinology 35 347-352. (doi:10.1111/j.1365-2265.1991. tb03547.x)

Terrell CL 1999 Antifungal agents. Part II. The azoles. Mayo Clinic Proceedings 74 78-100. (doi:10.4065/74.1.78)

Van Allen EM \& Ryan CJ 2009 Novel secondary hormonal therapy in advanced prostate cancer: an update. Current Opinion in Urology 19 315-321. (doi:10.1097/MOU.0b013e328329b73a)

Veytsman I, Nieman L \& Fojo T 2009 Management of endocrine manifestations and the use of mitotane as a chemotherapeutic agent for adrenocortical carcinoma. Journal of Clinical Oncology 27 4619-4629. (doi:10.1200/JCO.2008.17.2775)

Vignati F \& Loli P 1996 Additive effect of ketoconazole and octreotide in the treatment of severe adrenocorticotropin-dependent hypercortisolism. Journal of Clinical Endocrinology and Metabolism 81 2885-2890. (doi:10.1210/ jc.81.8.2885)

Wang T, Rowland JG, Parmar J, Nesterova M, Seki T \& Rainey WE 2012 Comparison of aldosterone production among human adrenocortical cell lines. Hormone and Metabolic Research 44 245-250. (doi:10.1055/s-00311298019)

Received in final form 2 October 2012

Accepted 4 October 2012

Made available online as an Accepted Preprint 4 October 2012 